\title{
Location, Location, Location: Place-Specific Human Capital, Rural Firm Entry and Firm Survival
}

\author{
Georgeanne M. Artz, Zizhen Guo, and Peter F. Orazem \\ gartz@iastate.edu; zizhenguo@gmail.com; pfo@iastate.edu
}

\section{GROWING SUBSET of economic development programs in the} United States are aimed at attracting or creating new firms. ${ }^{1}$ Firms less than five years old account for the vast majority of net new job creation in the United States. However, new firms are fragile: one-third of new start-ups fail within two years of opening and twothirds exit by their sixth year (Table 1). To succeed, economic development strategies must increase the pace of firm entry without altering the likelihood of failure. Designing such policies requires information on what factors contribute to the success or failure of new ventures, and how those factors vary across locations.

Our research suggests that the location choices of entrepreneurs are tied to the match between the entrepreneur and the location. A good match enhances firm productivity and increases firm survival in both rural and urban markets. We conjecture that the most successful entrepreneurs have some knowledge specific to their location, whether it is information on resources that can be exploited in a local area or local industry, ties to local sources of financing a start-up venture, or social networks that help attract and retain skilled labor or customers. We call this place-specific human capital. While this location-specific capital affects firm entry, it also plays a role in firm success and the value of the firm at the time of exit and succession.

Because most ventures fail, part of the expected value of the start-up is the value of the enterprise were it to be sold. If location-specific knowledge matters for success, the value at time of sale will depend on whether there are other potential buyers who share that knowledge. In denser urban markets, the likelihood of finding a potential successor with the requisite place-specific knowledge is high, and so there are many potential successors who could be as productive in the location. In rural markets, the opposite is true. As a result, rural entrepreneurs may continue to operate their businesses even if the realized profit stream is disappointing because they cannot find a successor willing to pay a sufficient amount to make the transition to a new owner attractive. In urban markets, even successful ventures may be sold for yet more promising ventures.

The importance of locationspecific capital in rural firm entry and survival has policy implications for rural business development policy. On the one hand, it suggests that place-based economic development policies aiming to encourage new start-ups should target individuals with the relevant types of location-

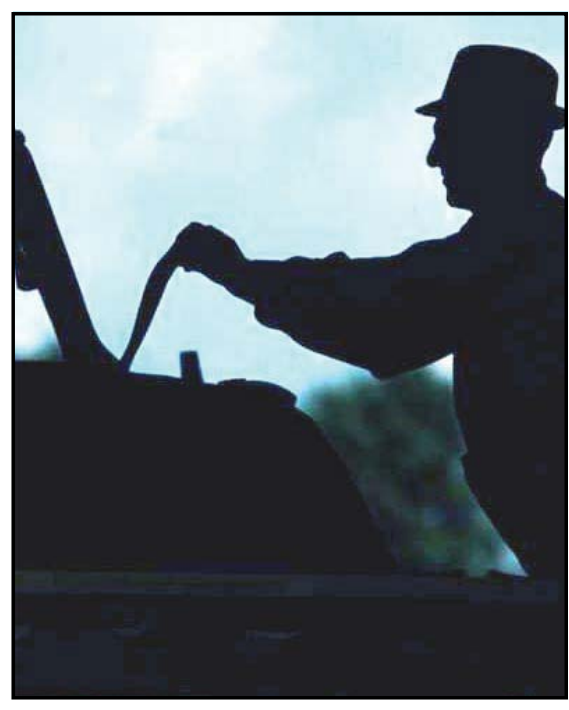

specific knowledge. On the other hand, it also suggests a need for rural business transition efforts to retain and perhaps grow existing viable rural businesses that lack a suitable successor.

Figure 1 shows the annual new firm entry rates for Iowa and North Carolina by rural and urban location between 1990 and $2010 .^{2}$ Rural entry rates are consistently lower than those in urban areas in both states-6.5 percent and 10.7 percent, for rural areas in Iowa and North Carolina, respectively, and 9.7 percent and 12.6 percent for urban areas in Iowa and North Carolina, respectively.

Data from Iowa and North Carolina, show that the same market factors that matter for firm entry in urban areas matter in rural areas as well. Both urban and rural start-ups are attracted to markets that already have some firms 미 
in the same industry, have better access to suppliers or customers, have higher concentrations of college-educated workers or higher income families, and have a diversified mix of local firms. In addition to these common market factors that raise firm profitability, our study measures the added value of place-specific knowledge in enhancing the profitability of firm entry.

We found that the entrepreneur's decision to enter a specific location was heavily influenced by placespecific knowledge and that the amount of place-specific knowledge significantly increased the likelihood of firm survival. Place-specific knowledge was even more important for the entry decision and survival of rural entrepreneurs. ${ }^{3}$

As shown in Table 1 the lower firm exit rates in rural markets are consistent with a presumption that the place-specific human capital is more important for the success of rural entrepreneurs than urban entrepreneurs.

However, it is also consistent with the presumption that there are more potential successors to an urban firm than a rural firm. Few potential buyers of the rural firm means a low salvage value of the rural firm compared to a comparable capital investment in an urban location. This implies that firms

\section{INSIDE THIS ISSUE}

Location, Location, Location: Place-Specific Human Capital, Rural Firm Entry and Firm Survival .......... 1

Biofuel and Feedstock Markets and the EU-US TTIP. . .4

Measuring Public Agricultural Research and Extension and Estimating their Impacts on Agricultural Productivity: New Insights from US Evidence. Farm Bill Payments in Iowa.. .6 Measuring Price Spreads in Red Meat. . .11
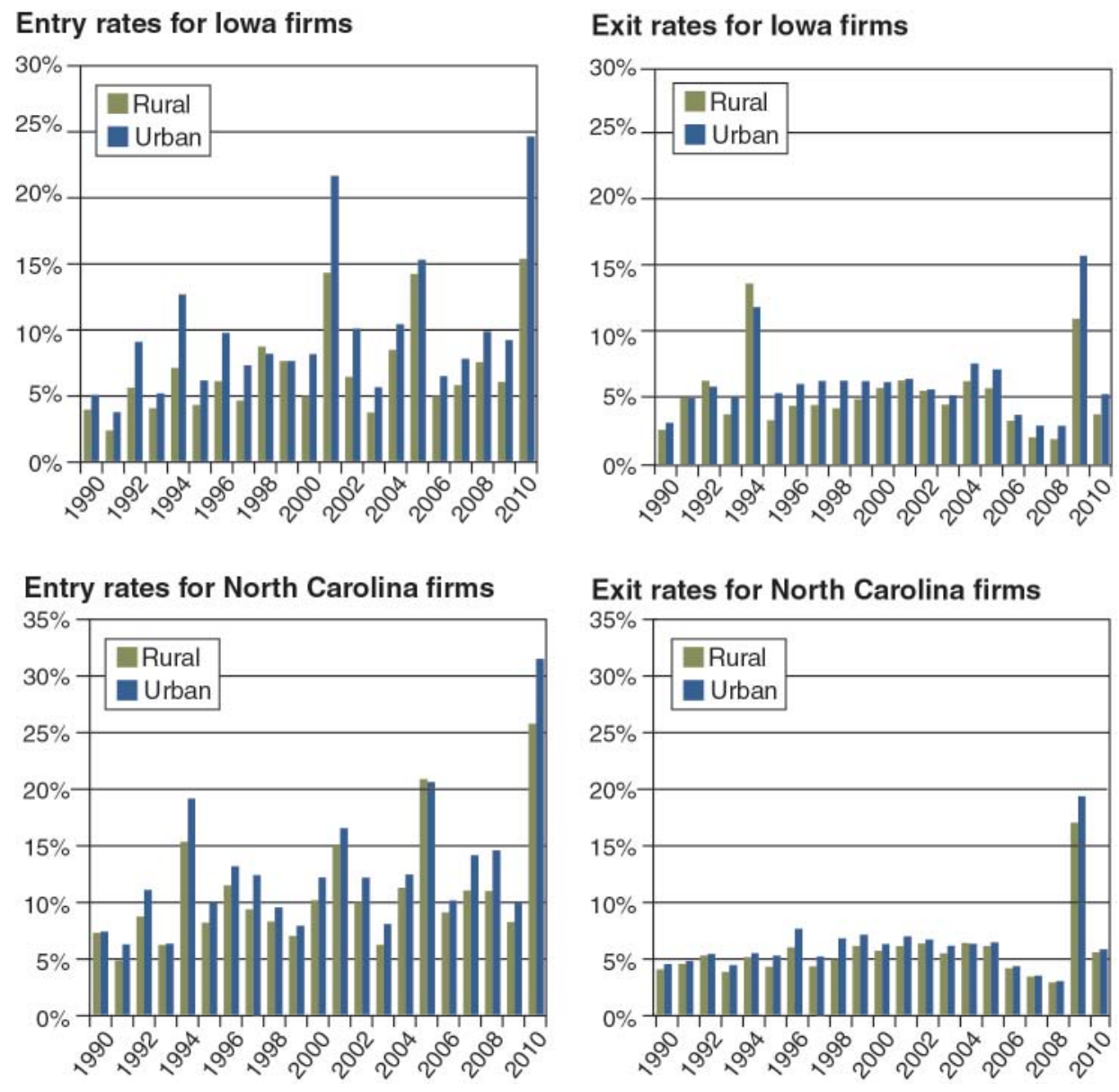

Figure 1. Firm entry and exit rates in lowa and North Carolina, 1990-2010.

that enter rural markets must have a higher expectation of success at the time of entry in order to compensate for these lower salvage values if the venture fails.

It is natural to think of longer surviving firms as a good thingfirms that stay in business longer are presumably profitable enough to keep operating. Firms that exit are often considered failures; however, there are various types of exit: bankruptcy, closure due to retirement or to pursue a different opportunity, and sale of the business. An entrepreneur's decision to exit is a function of the difference between the expected present value of profit from operating the business and the potential sell-off or salvage value of the firm, with higher salvage value increasing the likelihood of a "successful closure." The importance of place-specific human capital in business location choice, and business survival, has implications for exit as well. In urban markets, there is a ready supply of potential successors who have the same, or at least adequately similar, place-specific knowledge needed to successfully operate the business. In contrast, rural entrepreneurs may have a unique skill set that is atypically complementary with that location, and so when they are no longer operating the firm, the profitability of the successor at the location would be reduced.

Many long-running rural firms have faced problems finding successors. Family members are the most obvious successors, yet, the grown children of rural family-owned 
Table 1. Proportion of Rural and Urban Firms Exiting within 2 and 6 Years

\begin{tabular}{lccccc} 
& \multicolumn{2}{c}{ lowa } & \multicolumn{2}{c}{ North Carolina } & United States \\
\hline Exit within.... & Urban & Rural & Urban & Rural & All \\
\hline 2 years & $35 \%$ & $30 \%$ & $37 \%$ & $34 \%$ & $32 \%$ \\
6 years & $61 \%$ & $55 \%$ & $65 \%$ & $61 \%$ & $55 \%$ \\
\hline
\end{tabular}

Sources: Authors' computations from Walls and Associates, National Establishment TimeSeries data for lowa and North Carolina for business starting up between 1992 and 2008 , and from the US Bureau of Labor Statistics' Business Employment Dynamics for business starting up between 1994 and 2012.

operations often have established careers and little interest in succeeding their parents in running a "smalltown" business. In the United States, about 30 percent of family businesses are transferred to second-generation family ownership and only 13 percent survive to the third generation.

An alternative to family succession is transfer to an employee or a group of employees. Transition to employeeownership retains the firm-specific human capital embodied in the firm's workforce and may increase the probability that the business will continue to exist in its current location, benefitting both the employees themselves and the local community.

Absent a family or employee heir, finding a successor may be facilitated through matching programs such as AgLink, which matches retiring farmers who do not have an heir to continue the family farm business with beginning farmers who do not own land. A similar program for non-farm rural businesses, coupled with an apprenticeship program that would give the successor time to build skills and equity in the business, would be an additional way to address the thin markets problem for rural businesses.

${ }^{1} \mathrm{~A} 2012$ New York Times article estimates that local governments spend $\$ 80.4$ billion in business incentives each year, while state and federal sources contribute $\$ 170$ billion.

${ }^{2}$ Entry rates are calculated as the number of new firms divided by the number of existing firms. Similarly, exit rates are computed as the number of firms exiting in a year divided by the existing number of firms.

${ }^{3}$ This is consistent with the findings from a survey of Iowa State University alumni entrepreneurs that found that 37 percent of rural entrepreneurs started their businesses in their home county compared to only 19 percent of urban entrepreneurs. Presumably, place-specific human capital would be greatest in the location where an individual was raised.
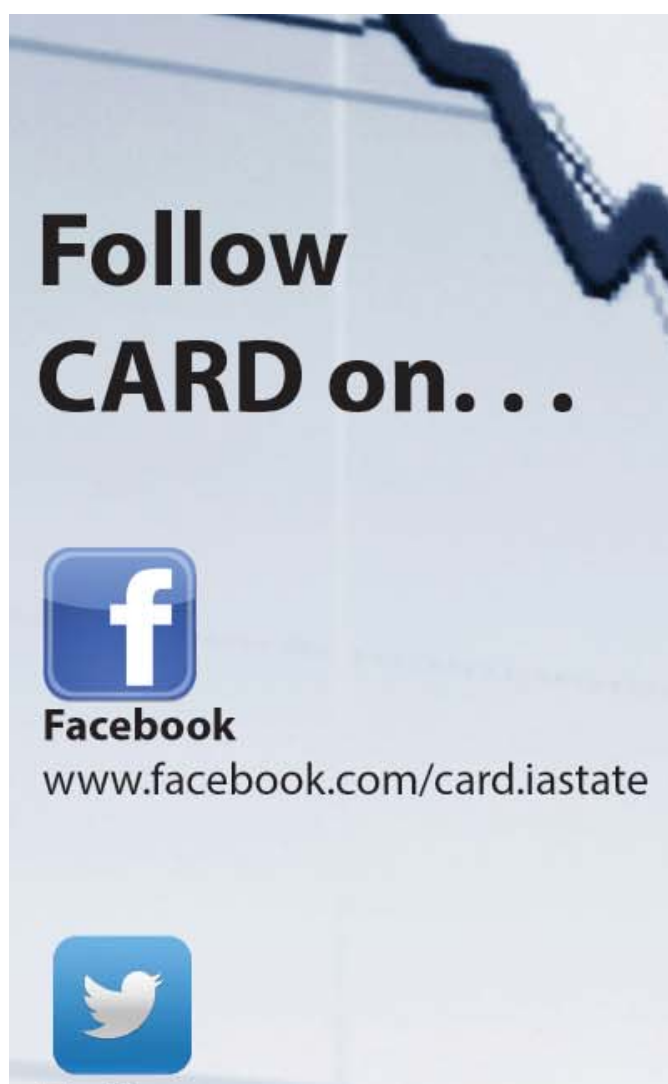

Twitter

www.twitter.com/CARD_ISU 


\section{Biofuel and Feedstock Markets and the EU-US TTIP}

\section{by John C. Beghin \\ beghin@iastate.edu}

A RECENT CARD analysis looked at the implications of a potential EUUS Transatlantic Trade and Investment Partnership (TTIP) for bioenergy and associated feedstock markets. This article reports on the effects of removing bilateral tariffs and TRQs in the two bio-economies. An extensive report is available on the CARD website.

\section{Notable policy distortions}

Policies in US and EU agricultural markets are less distorting than in the past, especially for grain and oilseed markets. Significant distortions remain in US sugar markets, however, as US sugar policy uses trade distortions (TRQ and associated high tariffs) to support prices. Domestic price levels historically have been two-to-three times the level of world prices. The out-of-quota tariff is $15.36 \mathrm{c} / \mathrm{lb}$ raw sugar and $16.21 \mathrm{c} / \mathrm{lb}$ for refined sugar. Free imports come from Mexico under NAFTA but are limited by the low competiveness of the Mexican sugar industry and by some rules of origin and side agreements. The US sugar lobby has been effective at limiting the influx of sugar imports under other agreements such as CAFTA, and the bilateral Australia-US agreement. Sugar policy in the European Union is in transition, as sugar production quotas will end in 2017-a major change for that sector. Since 2006, the EU sugar sector has been rationalized and quotas ensure high guaranteed prices. However, despite protections, EU sugar production is more competitive than its US counterpart. Under a TTIP, high prices in the US market would induce EU exports to the US market. Isoglucose (sugar made from grains

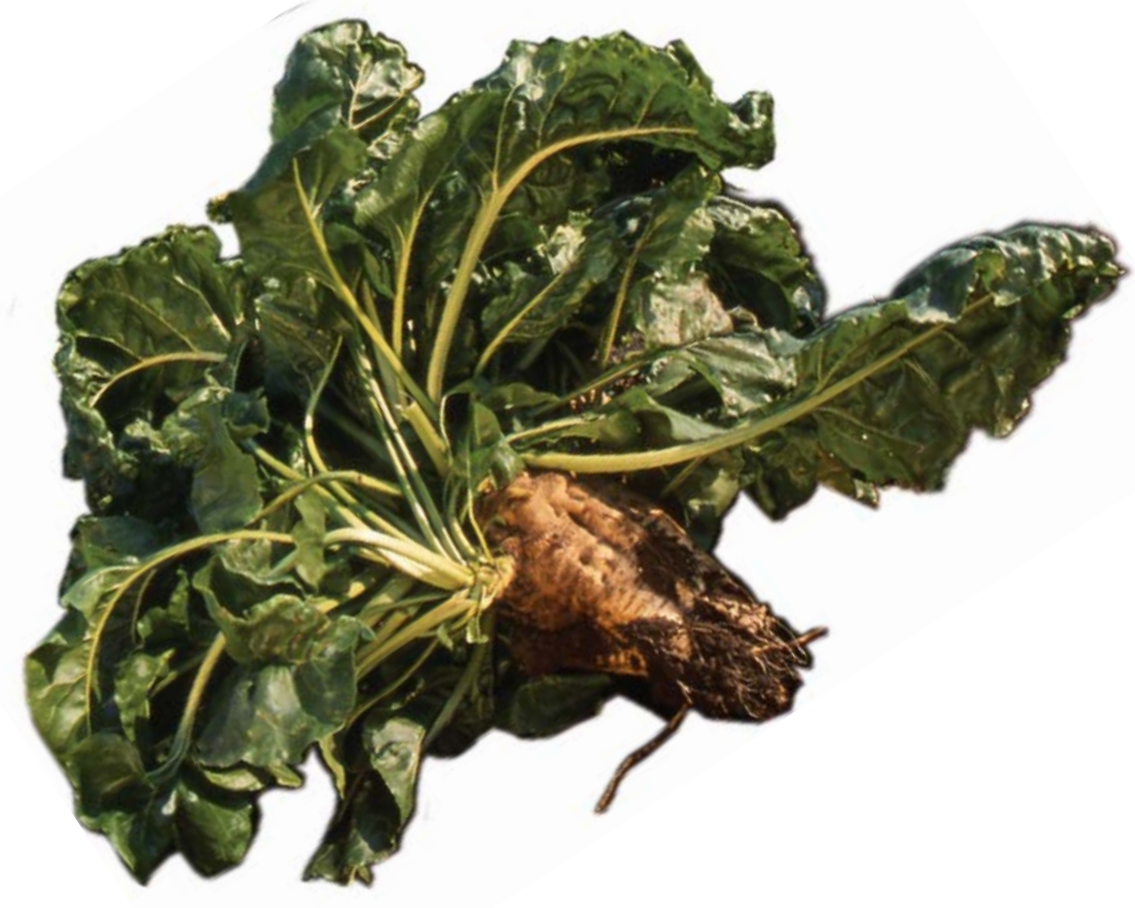

For biofuel use, raw sugar beets are processed to obtain refined sugar, which is then converted to ethanol. (Photo by Peggy Greb)

like HFCS) faces a duty of €507/MT of net weight. The United States faces this high tariff on its potential exports of HFCS. With bilateral liberalization, US HFCS would be competitive for use in EU food processing. Despite high sugar prices, the EU soft drink industry has not shifted to isoglucose to abate high sugar cost, in contrast to the US soft drink industry, which uses HFCS. This is due in part to EU isoglucose being constrained by production quotas to protect the EU sugar industry. These quotas will also be dismantled in 2017.

In biofuel markets, major distortions remain through mandates in both countries and through trade restrictions in the European Union. Border protection of ethanol in the European Union depends on preferential agreements and the statistical classification of ethanolrelated products. Numerous fuel blends are imported under different classifications. The MFN tariff on ethanol for fuel is $€ 19.20 / \mathrm{hl}$ for undenatured ethanol, and €10.20/hl for denatured ethanol. Currently, the United States faces antidumping duties that will expire by 2018, outside the 2022 horizon of our analysis, hence we do not consider them.

\section{Removing bilateral tariffs and TRQs}

Table 1 (available at http://www.card. iastate.edu/ag_policy_review/ ) shows supply changes (production, aggregate imports), changes in use (feed, food, industrial, aggregate exports), and price changes. For each variable, the percent change is shown along with the 2022 baseline level. The liberalization of trade between the European Union and the United States has a large impact on ethanol markets. In the European Union, ethanol price falls by 15 percent and there is a massive increase in imports (from the United States) and a substantial fall in ethanol output as well for DDGs. In the United States, production 
is stimulated and exports more than double (121 percent increase) stimulated by the EU trade opening and higher prices. Exports of DDGs expand by 40 percent and its price falls because of the near fixity between ethanol and DDGs. Feedstock use in each region experiences associated changes.

In the European Union, feedstock use (coarse grains and wheat in industrial use) and associated imports fall along with the price of coarse grains; lower DDG output is compensated by larger DDG imports. In the United States, the reverse occurs, with an expansion of coarse grains used in industrial use (ethanol), a reduction of coarse grain exports, and a small increase in coarse grain production responding to higher corn prices.

Changes in the bio-diesel markets echo the changes in the ethanol markets. EU biodiesel production contracts by three percent and imports expand by 23 percent. In the United States, biodiesel expands by 19 percent and exports more than double to the European Union. The vegetable oil and oilseed use follow these changes in biodiesel markets. In the European Union, industrial use of oils contracts by nearly four percent, oil and meal production contract by two percent and so does the volume of oilseeds crushed. Meal imports from the United States make up for the reduced domestic availability of EU meal. US oil and meal production expands by roughly 13 percent with more oilseeds being crushed (a 15 percent increase in industrial use) and fewer oilseeds being exported (an 18 percent reduction). Given the small changes in relative prices for grains and oilseeds, the changes in production for these commodities are small in both countries.

Changes in sweetener markets are the third important set of results in the simulations. Sugar trade liberalization between the European Union and the United States induces a massive contraction of both raw and refined sugar productions (34 percent and 38 percent, respectively) in the United States and a humongous increase (480 percent) in imports of refined sugar (mostly sugar coming from EU white sugar). Raw sugar imports into the United States contract given the availability of inexpensive white sugar and the contraction of the US canerefining sector and sugar prices fall by 18 percent (raw) and 15 percent (refined). Beet and cane productions contract by 36 percent and 34 percent, respectively, with falling farm prices.

Sugar prices remain above the loan rate levels for sugar. Food use of white sugar increases by 12 percent. Losses to US sugar crop producers and processors are substantial.

Conversely in the European Union, sugar production expands by 21 percent to export to the United States (an increase of 367 percent from a small base to 1,249 MT). EU beet output increases by four percent. Beets are also grown for ethanol, which explains the smaller relative increase in EU beet output relative to the EU white sugar expansion. The EU white sugar price increases by roughly four percent and white sugar consumption falls by a bit more than one percent.

The changes in the isoglucose/ HFCS markets are more convoluted. EU protection disappears, inducing a modest decrease in EU prices and a modest HFCS trade flow from the United States to the European Union. In addition, powerful indirect effects occur in food processing. In the United States, cheaper sugar is substituted for HFCS, and in the European Union, cheaper HFCS is substituted for sugar. Consumption of the sweetener composite sugar-HFCS increases in the United States but falls slightly in the European Union, where isoglucose production increases because grain prices have fallen and margins have improved despite the loss of protection at the border. In the United States, production of HFCS falls because of the reduced use of HFCS in food processing, lower output prices, and deteriorating margins from higher corn prices. Production of gluten feed, the byproduct of HFCS/isoglucose follows the directions taken by HFCS/isoglucose in the two regions with a smaller effect in the European Union, given that other grains are used for isoglucose production. 


\title{
Measuring Public Agricultural Research and Extension and Estimating their Impacts on Agricultural Productivity: New Insights from US Evidence
}

\author{
by Yu Jin and Wallace E. Huffman \\ yjin.sufe@gmail.com; whuffman@iastate.edu
}

\section{I}

N ORDER to feed the growing

population of the world, expected to reach 9.6 billion people-a 29 percent increase over 2013-by 2050 without causing immense environmental damage and hunger, society must increase agricultural productivity. Investing further in public agricultural research and extension will help alleviate this problem. Developed countries, like the United States, have been a leader in this area for most of the twentieth century. For example, US public agricultural research grew rapidly from 1960-1980, but slowed considerably from 1980-1995, showed negative growth from 1995-1998, then flattened by 2010 .

Rapidly developing countries, such as Brazil and China, are investing heavily in agricultural research, putting the future international competitiveness of US agricultural exports at risk. Future investments in public and private agricultural research and extension may not be large enough to deliver declining real world food prices, leaving consumers worse off. Moreover, those currently engaged in public agricultural science and agricultural extension policy debates need up-todate estimates of the expected returns on investment of public funds in both of these activities.

In the United States, agricultural research and cooperative extension are separate public programs, each jointly funded primarily by the federal and state governments. Public agricultural research is undertaken primarily by state institutions, such as state agricultural experiment stations (SAES) and veterinary medicine colleges/ schools, and federal institutions such as the USDA's Agricultural Research Service (ARS) and Economic Research Service. In addition, public agricultural research received a small amount of funding from the private sector and from non-governmental organizations and public extension receives significant funding from county governments.

Although SAES were established to conduct original research on agriculture, the breadth of the research undertaken has increased over time to include research on improving the rural home and rural life, agricultural marketing and resource conservation, forestry and wildlife habitat, and rural development. In addition, the breadth of research undertaken by the USDA has expanded through new institutions. For example, in 1924, the Bureau of Home Economics was established, and in 1957, the Home Economics Division and Utilization Division, which focused on post-harvest agricultural research, were combined into the Nutrition, Consumer, and Industrial Uses Division.

As part of the federal-state partnership on funding of public agricultural research, the USDA's intramural research agencies, SAESs, state forestry schools, and other cooperating institutions agree to provide Current Research Information System (CRIS) data on research projects. Hence, the range of research topics covered by US public agricultural research data span traditional crop and livestock production, diseases, pests, and resources, and also forestry research, post-harvest research (food processing, agricultural marketing and agricultural policy), rural and community development research, and home economics and human nutrition research.

However, with the details available in CRIS, it is possible to relatively accurately net out public agricultural research expenditures that clearly do not have a traditional agricultural productivity focus. How much of a difference does it make? In 1970, 70 percent of the US total expenditures on public agricultural research reported to CRIS were on agricultural productivityoriented research, but that has been slowly declining. In ARS, a significantly larger share of research undertaken is agricultural productivity oriented than in the state public agricultural research system. Public agricultural research undertaken in one state produces discoveries benefiting local farms and agri-businesses but also spilling over to the public and private agricultural research efforts in other states and to technologies available to farms and agri-businesses in these areas. Spillover benefits are linked to similarity of agroecological zones, output-mix similarities, or geographical proximity.

When areas are close to one another it reduces the physical distance that discoveries and information must travel before they can be used by farmers and agribusiness in another area. This reduces one dimension of the costs of information transfers. For example, discoveries made by public agricultural research in Iowa on corn can easily travel to agribusinesses and farmers in Illinois and southern 
Minnesota but are less useful to Mississippi and New York.

Extension is primarily adult education for immediate decision making of farmers, households, and communities and youth activities. Broadly, the goal has been to provide information for better farm, agribusiness and home decision making. Youth activities are comprised of "boys" and "girls" clubs, called "4$H$ " clubs, where members undertake practical projects in agriculture, home economics, and related subjects, such as developing a product to "show" and be "judged" at a local county fair, (e.g., fattened lambs or pigs, baked cookies or cakes, canned fruits, etc.). The science of these 4-H projects has been roughly comparable to high school science classes.

Although a gross measure of cooperative extension is possible, it seems most likely that only agriculture and natural resource extension contribute significantly to state agricultural productivity. This requires netting out resources allocated to other types of extension activities (i.e., home economics, community development and 4-H). How much of a difference is their between the net and gross measures of cooperative extension? From 1977 to 1992, only 55 percent of the gross activities were for agricultural and natural resource extension. In addition, in 1977, 30 percent of the gross extension was allocated to $4-\mathrm{H}$, but this share declined to 23 percent in 1992 and seemingly leveled off.

Real expenditures on public productivity-oriented agricultural research undertaken by state and USDA institutions grew at an average rate of 3.2 percent, from 1960 to 1980; however, its growth slowed to 0.9 percent from 1980 to 1990 , then fell to -0.8 percent from 1990 to 2009. In particular, real public agricultural research effort peaked in the United States in 1994, and then was 22 percent lower in 2009. To give a little more perspective, in California, Iowa, North Carolina, and Texas productivity-oriented public agricultural-research expenditures peaked in the late 1980s and the early to mid-1990s (see Figure 1).
Using new and updated data and allowing for lags in realizing within state and interstate spillover benefits, this study estimates that the real annual internal rate of return to investments in productivity-oriented public agricultural research is 67 percent and for agricultural and natural resource extension is over 100 percent. These are large returns that have not been matched by other public sector investments. Hence, there is no evidence of low returns to public agricultural research or extension in the United States, or that public funds should be shifted from public agricultural extension to agricultural research.

Other countries can learn from the research undertaken in the United States to estimate rates of return to public agricultural research and extension. First, it is important to think carefully about and identify plausible benefits and costs. In particular, one should guard against creating variables that contain obvious forms of measurement error, such as inaccurately measuring the costs and benefits or aggregating public agricultural research and extension together.

\section{Million dollars}

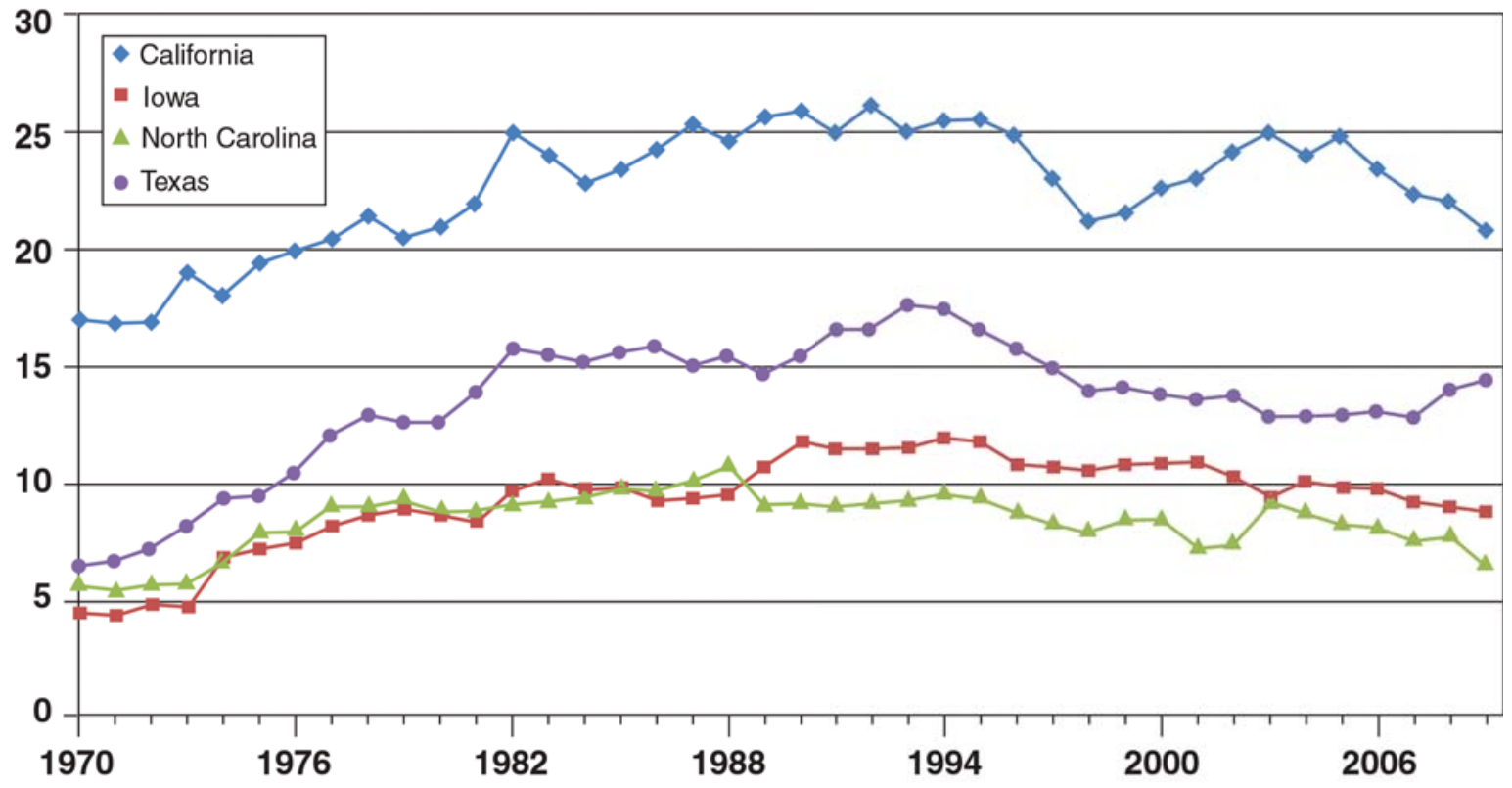

Figure 1. Real public agricultural research expenditures, CA, IA, NC, and TX, 1970-2009 (millions of 2006 dollars). 
by Alejandro Plastina, Chad Hart, and Christopher Anderson plastina@iastate.edu; chart@iastate.edu; cjames@iastate.edu

$\mathbf{I}_{\mathrm{p}}^{\mathrm{N}}$

N THE first half of 2015, crop

producers could elect each farm into one of the two new commodity programs introduced by the 2014 Farm Bill: Price Loss Coverage (PLC) or Agricultural Risk Coverage (ARC); the latter at the individual farm level (ARCIC), or at the county level (ARC-CO). Producers who wanted to participate in the commodity programs for the 2014 marketing year had to enroll their farms in the elected programs during the summer of 2015.

A total of 22,528,220 base acres of covered commodities were enrolled in the new programs in Iowa. Corn and soybeans accounted, respectively, for 69 percent and 30 percent of those base acres. Ninety-seven percent of all base acres were enrolled in ARC-CO. ARC-IC is excluded from this analysis due to lack of data.

\section{Payments in 2015}

In 2015, total ARC-CO payments in Iowa amounted to $\$ 908,914,323$. The average ARC-CO payment per corn and soybean base acre amounted to $\$ 48$ and $\$ 10$, respectively, after 6.8 percent sequestration. The payment per base acre was calculated as 85 percent of the difference between the county crop revenue and the ARC-CO guarantee revenue in 2014. The county crop revenue is the product of county yield times the national marketing year average price ( $\$ 3.70$ for corn and $\$ 10.10$ for soybeans). The ARC-CO guarantee revenue in 2014 was calculated as 86 percent of the product of the guaranteed price and the five-year Olympic average of the county yields in 2009-2013.

(The Olympic average is calculated as the simple average of the remaining numbers after eliminating the highest and the lowest from the calculation.) The guaranteed price in 2014 was calculated as the five-year Olympic average of the national marketing year average prices in 2009-2013, and amounted to $\$ 5.29$ per bushel of corn and $\$ 12.27$ per bushel of soybeans (see Ag Decision Maker File A1-32 for further details: http://bit.ly/ADMA132).

ARC-CO payments per corn base acre ranged from $\$ 0$ to $\$ 78.79$ (after sequestration) across counties (Figure 1, panel a). ARC-CO payments for soybean base acres ranged from $\$ 0$ to $\$ 51.71$ (after sequestration) across counties (Figure 1, panel b). Although the marketing year average price for soybeans was $\$ 2.17$ lower than the Olympic average price, most counties received very low payments due to record yields in 2014.

No PLC payments were triggered in 2015, since the 2014 marketing year average prices were equal to or higher than the reference prices established in the Farm Bill: $\$ 3.70$ per bushel of corn and $\$ 8.40$ per bushel of soybeans.

The projected gross margins (i.e., the difference between crop revenue and total costs) per rented acre using state average data for 2015 compute to negative $\$ 211$ for corn following corn, negative $\$ 104$ for corn following soybeans, and negative $\$ 103$ for soybeans (Plastina 2016). Even the highest ARC-CO payment, $\$ 78.79$ (O'Brien County), falls short of covering the negative margins on rented acres in 2015 .

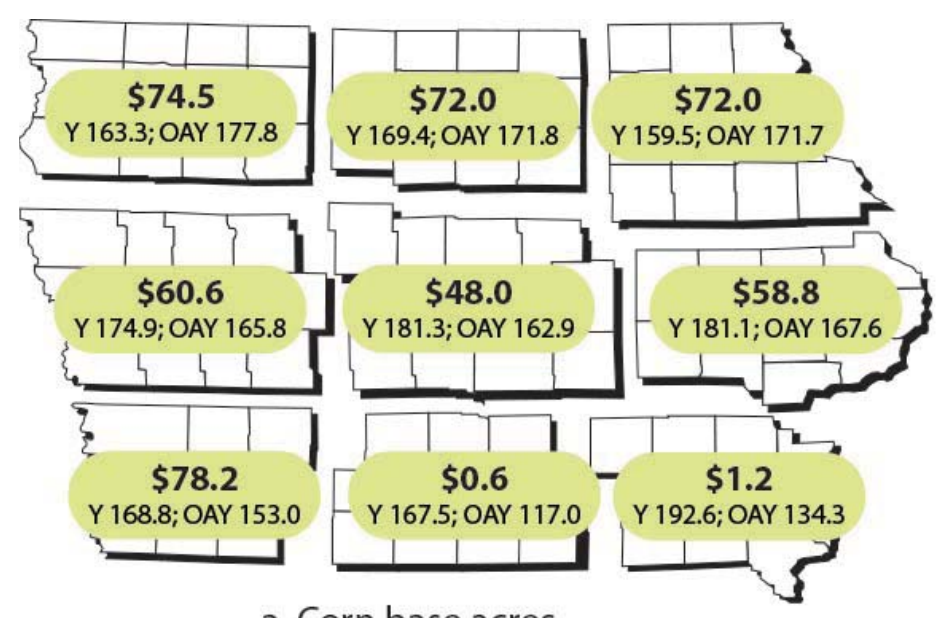

a. Corn base acres
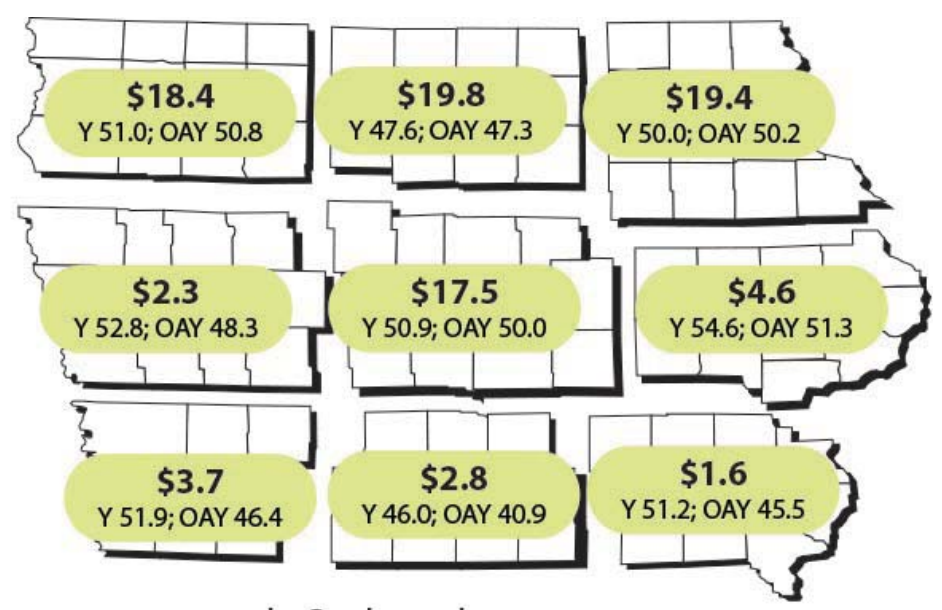

b. Soybean base acres

Notes: $\mathrm{Y}=$ average 2014 yields OAY = Olympic average yields in 2009-2013

Figure 1. Average ARC-CO payments for the 2014/15 marketing year by crop reporting district 


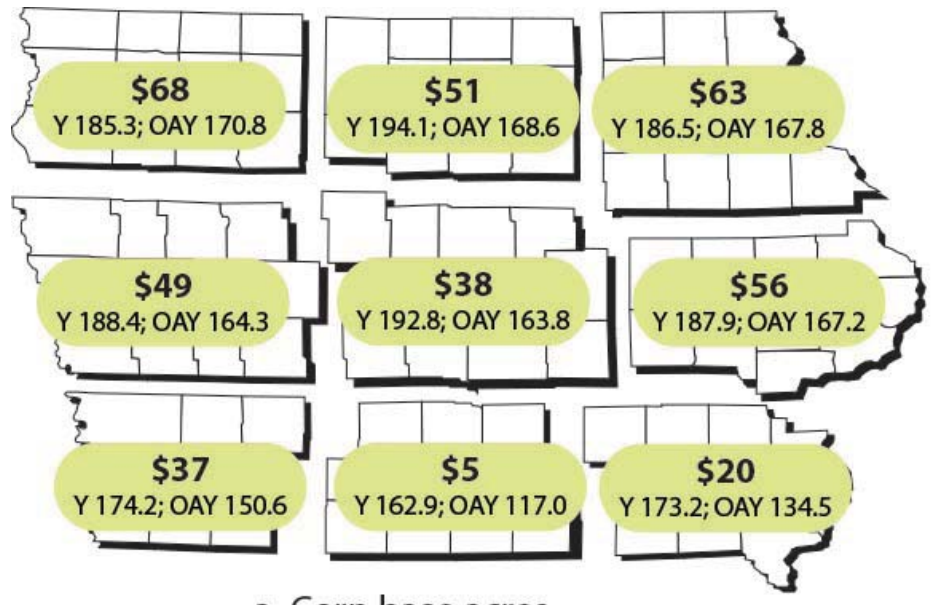

a. Corn base acres

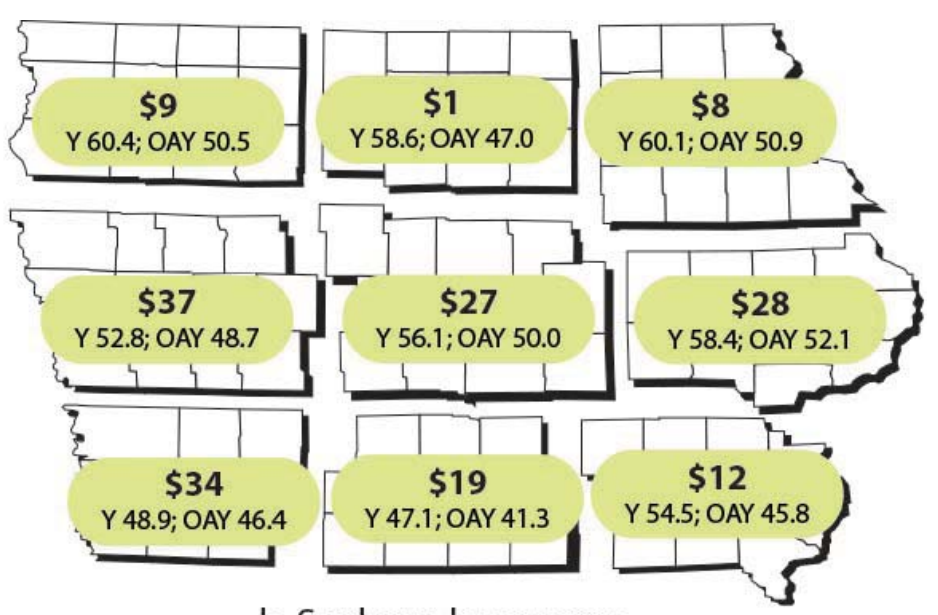

b. Soybean base acres

Notes: $Y=$ average 2015 yields

$\mathrm{OAY}=$ Olympic average yields in 2010-2014

Figure 2. Average ARC-CO payments projected for the 2015/16 marketing year by crop reporting district

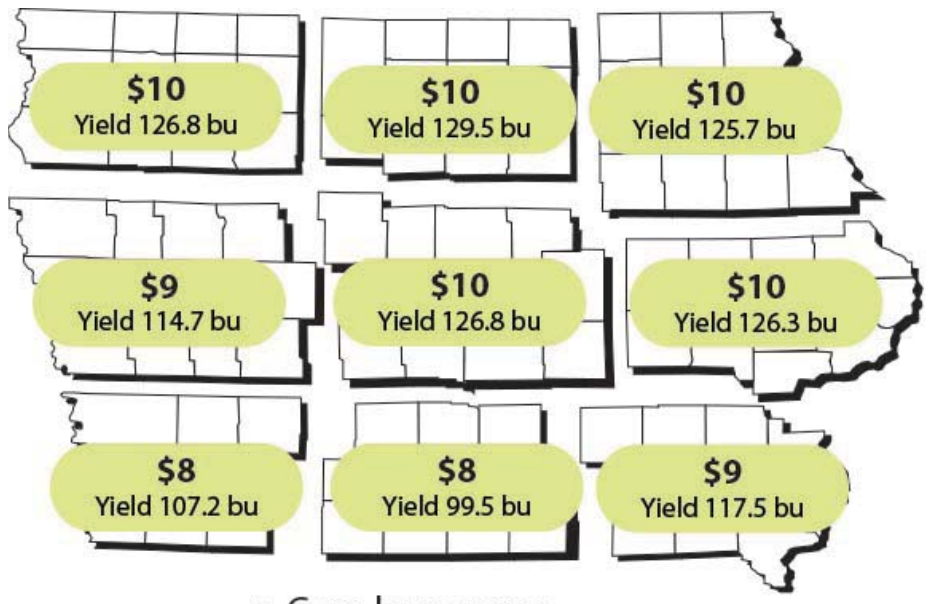

a. Corn base acres

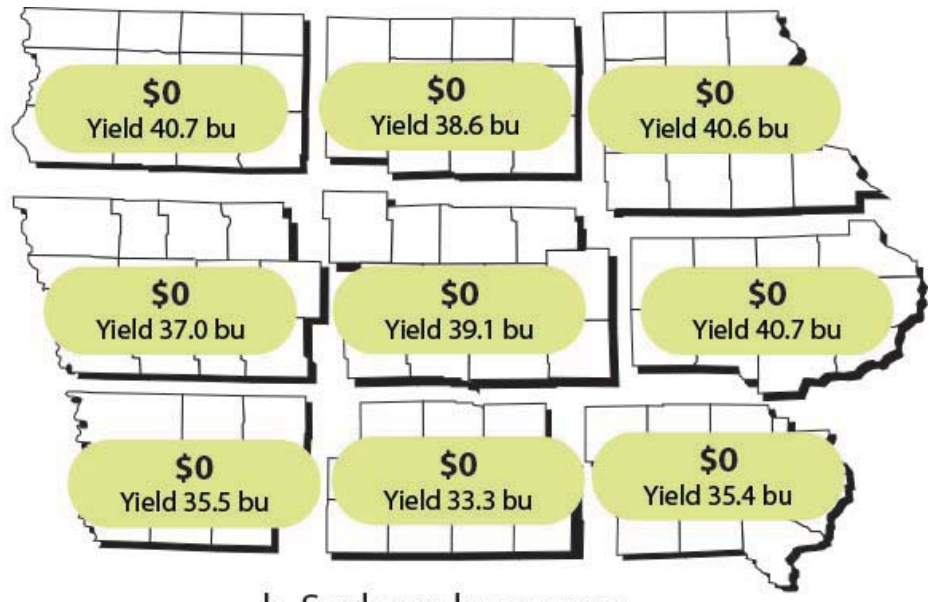

b. Soybean base acres

Notes: Yields are average Counter-Cyclical Payment yields

Figure 3. Average PLC payments for the 2015/16 marketing year by crop reporting district

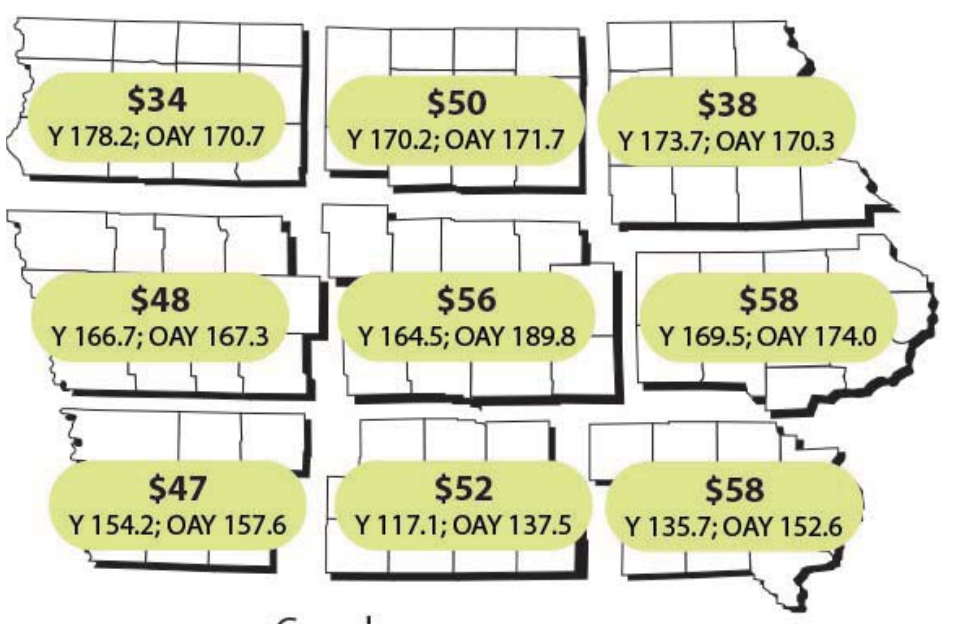

a. Corn base acres

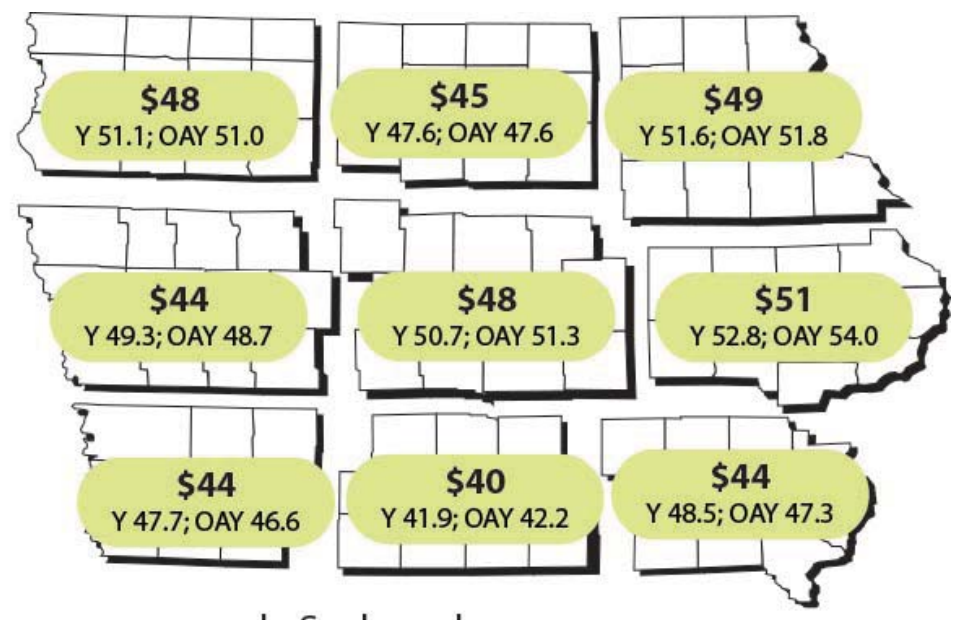

b. Soybean base acres

Notes: $Y=$ average 2016 yields

$\mathrm{OAY}=$ Olympic average yields in 2011-2015

Figure 4. Average ARC-CO payments projected for the 2016/17 marketing year by crop reporting district 


\section{Projected Payments in 2016}

USDA will issue ARC/PLC payments associated with the 2015/16 marketing year in October 2016. As of January 2016, two critical variables for the calculation of ARC/PLC payments are still unknown: the 2015 marketing year average price and the 2015 county yields. However, payments can be projected using USDA price projections and extrapolating county yields using official USDA state and regional yield estimates.

The current USDA price projections for corn and soybean in 2015 are, respectively, $\$ 3.60$ and $\$ 8.80$ per bushel. County yields are projected by multiplying 2014 county yields by the ratio of 2015 to 2014 yields in the corresponding crop reporting district (CRD). For example, the 2014 corn yield for Adair County was 164 bushels; the corn yields for CRD 7 were 175.4 bushels in 2014 and are projected at 181.0 bushels in 2015; and the 2015 corn yield for Adair County is projected at 169 bushels (=164 × 181.0/ 175.4).

The 2015 ARC-CO guaranteed prices are unchanged from 2014 , since the 2014 prices that are incorporated into the calculation of the rolling fiveyear Olympic average are the lowest prices in 2010-2014 and therefore do not affect the resulting average, just as 2009 prices did not affect the 2014 ARC-CO guaranteed prices.

Under the described assumptions, Iowa farmers would receive, on average, ARC-CO payments for $\$ 43$ per corn base acre and $\$ 19$ per soybean base acre in 2016. Projected yields in 2015 are higher than the Olympic average yields over 2010-2014 for all counties but Adams (soybeans), Lyon (corn), and east and west Pottawattamie (corn and soybeans). However, the projected prices would drive crop revenues below the ARC-CO guarantee revenues for corn and soybean base acres in 79 and 69 counties, respectively.
PLC payments in Iowa would average $\$ 9.50$ per corn base acre, but would be zero for soybean base acres (Figure 3). PLC payments are calculated as 85 percent of the difference between the marketing year average price and the reference price times the PLC payment yields for each farm. By default, PLC payment yields are the old Counter-Cyclical Payment Yields (CCPY). However, in the first semester of 2015 producers had a one-time opportunity to update their payment yields to reflect their recent production history (2008-2013). At the national level, 31 percent of the farms electing PLC on corn base acres (accounting for 48 percent of the corn base acres in PLC) and 45 percent of the farms electing PLC on soybean base acres (accounting for 60 percent of the soybean base acres in PLC) updated their yields. The new yields for corn and soybeans were, on average, 28.3 percent and 31.5 percent higher than the CCPY, respectively. However, updated yields are not publicly available, so all calculations in this article are based on CCPY.

The projected gross margins per rented acre in 2016 compute to negative \$151 for corn following corn, negative $\$ 51$ for corn following soybeans, and negative $\$ 115$ for soybeans (Plastina 2016). There are 51 counties where projected ARC-CO payments exceed $\$ 51$ per corn or soybean base acre, but the highest projected payment (corresponding to O'Brien County), amounts to $\$ 75.85$.

\section{Projected Payments for 2017} If 2015/16 USDA price projections materialize, 2014/15 prices will replace $2010 / 11$ prices in the five-year Olympic average calculation, and the ARC-CO guarantee prices for 2016/17 will be 9 percent and 3 percent lower for corn and soybeans, respectively, than in the previous two years: $\$ 4.79$ and $\$ 11.87$ per bushel. As a result, the 2016/17 ARC-CO guarantee revenue for corn and soybean base acres would be $\$ 37$ and $\$ 8$ lower, on average, than in 2015/16. However, 19 counties would see their ARC-CO guarantee revenue go up on corn base acres (mostly in CRDs 8 and 9), and 26 counties would benefit from higher ARCCO guarantee revenue on soybean base acres (concentrated in CRDs 5, 6, and 9).

County yield forecasts for 2016 were provided by the Iowa State University Climate Science Program, based on an index of El Niño strength as of October-December 2015. Projected yields are lower than the five-year Olympic average yields in 61 counties for corn base acres and 39 counties for soybean base acres.

The 2016/17 marketing year average price is projected using futures market prices (Hart 2014) at $\$ 3.76$ per bushel of corn and $\$ 8.53$ per bushel of soybeans (as of January 14, 2016). The difference between the projected price and the ARC-CO guarantee price, after 6.8 percent sequestration would be $\$ 0.96$ per corn base acre and $\$ 3.34$ per soybean base acre.

ARC-CO payments in Iowa would average $\$ 49$ per corn base acre and $\$ 46$ per soybean base acre in 2017 (Figure 4). All counties would receive payments for soybean base acres, and all but Lyon and Sioux Counties (due to high projected yields) would receive payments for corn base acres.

Since the projected marketing year average prices for 2016/17 exceed the reference prices for PLC, no PLC payments are expected in 2017.

\section{References}

Hart, Chad. 2014. “USDA's Season-Average Commodity Prices." Ag Decision Maker. File A2-15.

Plastina, Alejandro 2016. “2016 Gross Crop Margins Negative despite Lower Costs.” Ag Decision Maker Newsletter. Vol 20, no. 3. 


\section{Measuring Price Spreads in Red Meat}

\section{by Sebastien Pouliot and Lee Schulz}

pouliot@iastate.edu; Ischulz@iastate.edu

$\mathbf{H}$

IGH AND increasing price

spreads in red meat often lead to controversy-livestock producers tend to blame low livestock prices on high price spreads, and consumers blame high retail prices on high price spreads. Increasing price spreads can both inflate retail prices and deflate farm prices. The intertemporal relationships among live, wholesale, and retail beef and pork prices are important issues in effectively analyzing and monitoring the efficiency and equity of the red meat marketing system. Knowledge of how these prices react to one another is useful for private as well as public policy decision making.

Price spreads, or marketing margins, are the difference between prices at different stages of the supply chain. The wholesale-to-retail spread is the difference between the wholesale price and the retail price. The farmto-wholesale spread is the difference between the wholesale price and the net farm price (net farm price is the gross farm price minus the value of byproducts per unit). The total spread is the sum of the farm-wholesale and wholesale-retail spreads, which can also be calculated by subtracting the net farm price from the retail price. For example, if the wholesale price is $\$ 2.00 / \mathrm{lb}$ and the farm price is $\$ 1.50$ / $\mathrm{lb}$, the farm-to-wholesale spread is $\$ 0.50 / \mathrm{lb}$. With a retail price of $\$ 3.00$ / $\mathrm{lb}$, the farm-to-retail spread is $\$ 1.50$ / $\mathrm{lb}$ and the wholesale-to-retail spread is $\$ 1.00 / \mathrm{lb}$. Figure 1 shows monthly price spreads for beef and pork in the United States from January 2000 to December 2015 as calculated by the US Department of Agriculture's Economic Research Service (ERS). The burgundy area labeled "Farm" is the value created
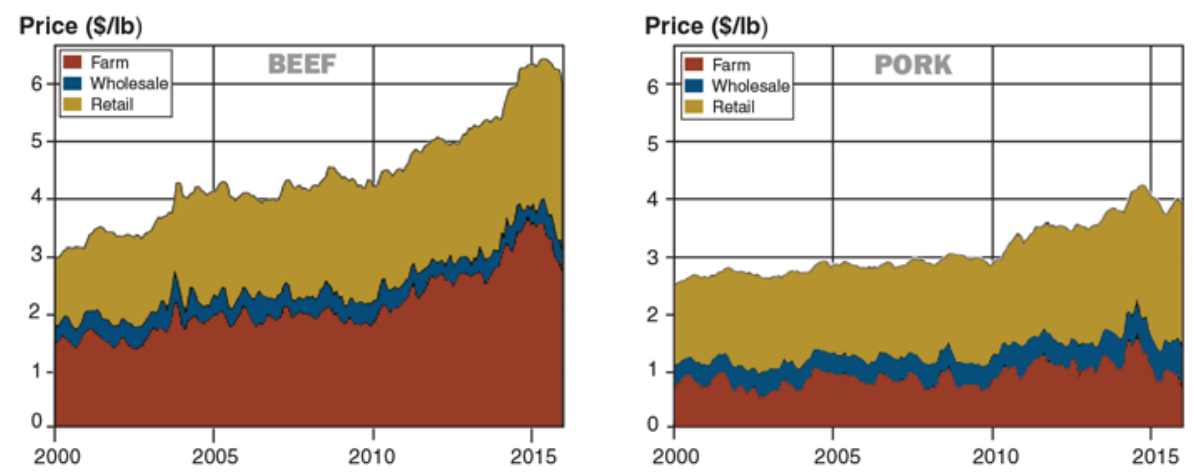

Figure 1: Price spreads for beef and pork, 2000-2015, monthly
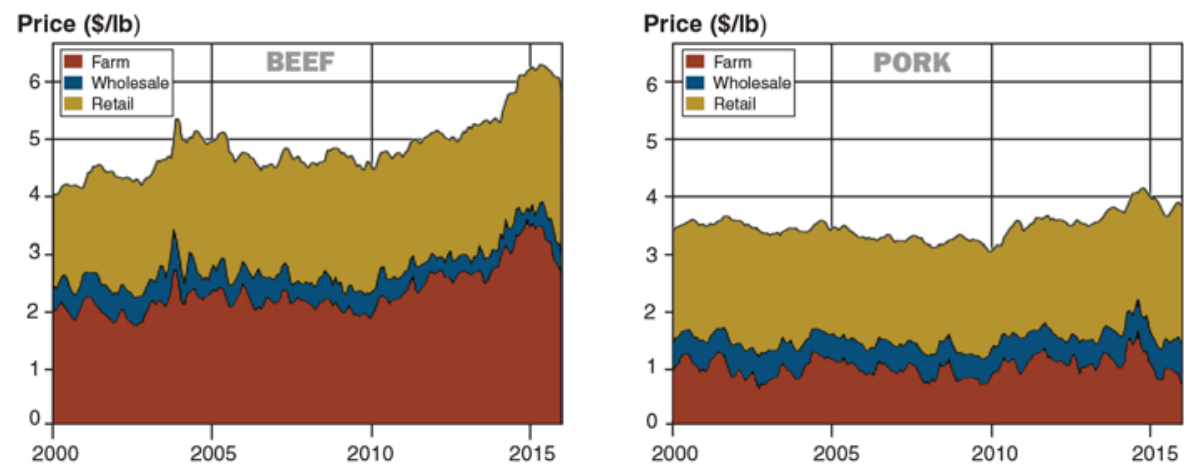

Figure 2. Price spreads for beef and pork (CPI, January 2015=100), 2000-2015, monthly
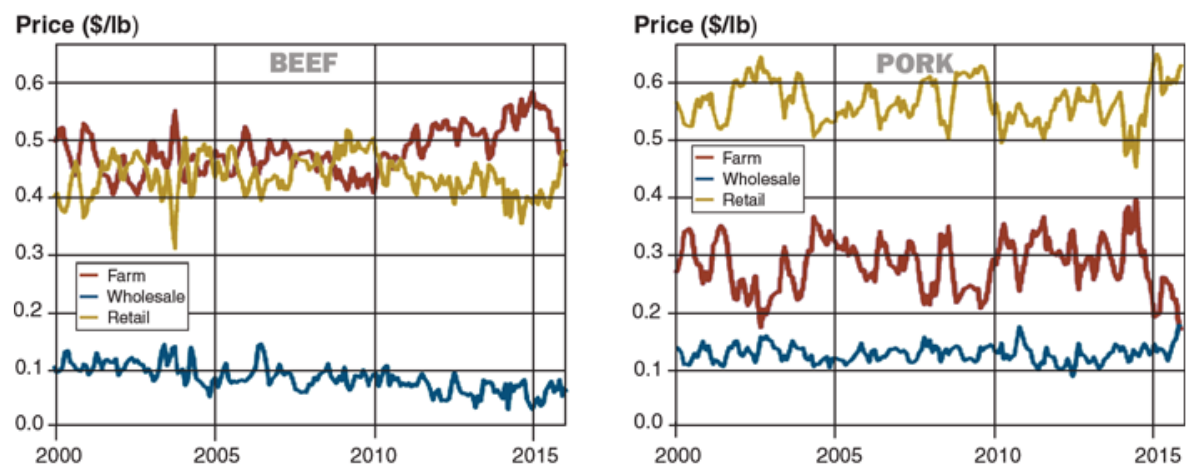

Figure 3: Value shares for beef and pork from retail equivalent prices

at the farm. The dark blue area labeled "Wholesale" is the farm-to-wholesale spread. The black line between the Farm and the Wholesale areas is the price paid to farms. The brown area labeled "Retail" is the wholesale-toretail spread. The black line between the wholesale and the retail areas is the wholesale price. The black line at the top of the brown area is the retail price.
The total farm-to-retail spread has been increasing primarily because of increase in the wholesale-to-retail spread, and in the case of beef because of an increase in farm price. The wholesale-to-retail spread is a measure of the margin that the retail segment has extracted. It is made up of retailers' costs and their profit margins, and while it is impossible to infer from the 
figure whether the increase is due to increasing costs or to increasing profits, retailers' total operating margin has expanded significantly and persistently.

ERS calculates price spreads based on composite meat products with definitions remaining constant throughout the series plotted in Figure 1 . This means that although grocery stores are selling increasing quantities of boneless and value-added meat products, the definitions of the meat products used by ERS remain constant over time (ERS redefines composite meat products on occasion to adjust for changes in industry practices.) In addition, the definitions of the composite products remain constant within the supply chains so that prices in Figure 1 are all reported given the composition of products sold at retail. The values used in Figure 1 are in nominal terms, meaning they have not been adjusted for inflation.

A more nearly-correct way to look at the spreads would be to remove the influence of inflation and then examine the patterns. If packers, for example, are able to keep the increase in the margins they extract to an amount exactly equal to the inflation rate, then the inflation-adjusted spread would be flat and a horizontal line on the graph. With increased efficiencies, especially significant economies of size associated with the large packing plants being realized, then the inflation-adjusted margins could actually trend down over time. Conversely, if middlemen have not accumulated cost-reducing efficiencies, then the inflationadjusted spread will trend higher. An upward trend in an inflation-adjusted spread means that the middlemen are extracting a margin that is growing more rapidly than the inflation rate, and they are either taking a larger profit margin or are extracting a larger margin to cover rising costs.

Figure 2 shows the inflationadjusted spreads, and the message they offer is revealing and important. The retail inflation-adjusted price in beef has increased, while remaining relatively constant for pork. In beef, the rise in the retail price is mostly due to an increase in the farm price, while the farm-to-wholesale spread has narrowed and the wholesale-toretail spread has remained constant. In pork, the spreads have stayed relatively constant.

Figure 3 presents data that show implicitly the spreads in a format that many market participants use. Lines represent the share of retail dollar accrued at the farm, wholesale and retail level. For example, at the end of 2015, for a dollar spent on beef about 45 cents went to the farm (producers), about 10 cents to wholesale (packers), and about 45 cents to retail (grocers). Value shares are not sensitive to inflation.

The shares in Figure 3 confirm conclusions based on Figure 2 . In beef, the farm value share has increased since 2000, the wholesale value share has declined, and the retail value share has remained relatively constant. In pork, all value shares have stayed relatively constant since 2000. Figure 3 is especially useful to describe what has occurred in recent months. The decline of livestock prices has caused the farm value share to decline for both beef and pork. In beef, this has resulted in an increase in the retail value share, but in pork it is a combination of an increase in wholesale and retail value shares. However, Figure 2 shows that the declines in farm prices have been largely passed to consumers as retail prices have declined.

Recurrent accusations by consumer and producer groups of retailers failing to react to declining livestock prices cannot be substantiated based on Figures 2 and 3. It takes time for prices to adjust, and they tend to adjust more rapidly when they are increasing than when they are decreasing. Thus, even if the recent decline in farm prices has not yet been entirely passed to consumers, we expect the pass-through to more fully adjust in the next few months, such that we observe further decline in prices for red meat at retail.

\section{www.card.iastate.edu}

$\begin{array}{ll}\text { Editor } & \text { Advisory Committee } \\ \text { Catherine L. Kling } & \text { Bruce A. Babcock } \\ \text { CARD Director } & \text { John Beghin } \\ \text { Editorial Staff } & \text { Chad Hart } \\ \text { Nathan Cook } & \text { Dermot J. Hayes } \\ \text { Managing Editor } & \text { Helen H. Jensen } \\ \text { Curtis Balmer } & \text { GianCarlo Moschini } \\ \text { Web Manager } & \text { Sebastien Pouliot } \\ \text { Rebecca Olson } & \text { Lee Schulz } \\ \text { Publication Design } & \end{array}$

Agricultural Policy Review is a quarterly newsletter published by the Center for Agricultural and Rural Development (CARD). This publication presents summarized results that emphasize the implications of ongoing agricultural policy analysis of the near-term agricultural situation, and discussion of agricultural policies currently under consideration.

Articles may be reprinted with permission and with appropriate attribution. Contact the managing editor at the above e-mail or call 515-294-3809.
Subscription is free and available on-line. To sign up for an electronic alert to the newsletter post, go to www. card.iastate.edu/ag_policy_review/subscribe and submit your information.

Iowa State University does not discriminate on the basis of race, color, age, ethnicity, religion, national origin, pregnancy, sexual orientation, gender identity, genetic information, sex, marital status, disability, or status as a U.S. veteran. Inquiries can be directed to the Interim Assistant Director of Equal Opportunity and Compliance, 3280 Beardshear Hall, (515) 294-7612. 